\title{
Diphtheria-neutralizing antibody levels in healthy adults from Rio de Janeiro, Brazil
}

\author{
Fabricia Pires Pimenta, Paulo Vieira Damasco/*, José Cerbino Neto**, \\ Guilherme Santoro Lopes***, Raphael Hirata Jr, Lucimar Gonçalves Milagres, \\ Ana Luíza Mattos-Guaraldi ${ }^{+}$
}

Faculdade de Ciências Médicas, Universidade do Estado do Rio de Janeiro, Av. 28 de Setembro 87, Fundos, $3^{\circ}$ andar, 20551-030 Rio de Janeiro, RJ, Brasil *Escola de Medicina e Cirurgia, Universidade Federal do Estado do Rio de Janeiro, Rio de Janeiro, RJ,

Brasil **Setor de Doenças Imunopreveníveis, Secretaria Estadual de Saúde, Rio de Janeiro, RJ, Brasil ***Departamento de

Medicina Preventiva, Universidade Federal do Rio de Janeiro, Rio de Janeiro, RJ, Brasil

In Brazil, until 2004, the immunization policy against diphtheria involved childhood vaccination with no official routine booster dose administered after 15 years of age. This study assessed functional antibody levels against diphtheria among blood donors. A total of 140 blood samples were collected, and diphtheria antitoxin levels were evaluated by Vero cell neutralization test. The mean age of the population was 34 years old (range: 1861 years); $37.8 \%$ females and $62.2 \%$ males. Overall, 30.7\% (95\%, CI: 23.4-38.7) individuals presented neutralizing antitoxin antibody titers < $0.01 \mathrm{IU} / \mathrm{ml} ; 42.1 \%$ (95\%, CI: 34.1-50.4) showed values between 0.01-0.09 IU/ml and, 27.1\% (95\%, CI: 20.2-34.9) had $\geq 0.1 \mathrm{IU} / \mathrm{ml}$. In the subgroup of individuals with history of diphtheria immunization during childhood (85\%), a number of $28.5 \%$ showed unprotective levels of circulating neutralizing antibody (< $0.01 \mathrm{IU} / \mathrm{ml}$ ). Despite the continuous progress of immunization programs directed to Brazilian population, currently healthy adults remain susceptible to diphtheria.

Key words: diphtheria - diphtheria antitoxin - Vero cells assay - Rio de Janeiro - Brazil

The vast territory and unfavorable economic conditions presented by most regions of our country make difficult the notification of diphtheria cases to Public Health authorities and remittance of suspect isolates for bacteriological confirmation and toxigenicity tests to reference laboratories. Local outbreaks have been reported indicating gaps or failure in vaccine coverage (Mattos-Guaraldi et al. 2003).

Western Europe epidemics illustrated the potential susceptibility of adults to diphtheria in the vaccine era. Although the World Health Organization recommends evaluation of vaccine-induced immunity among both children and adults, a very few serosurveys have been done outside of North American and Western Europe continents (Damasco et al. 2005). Nationwide seroepidemiological studies are necessary to elaborate effective strategies to maintain immunity against diphtheria in adults, including periodic booster doses and immunization of selected age groups (Galazka \& Robertson 1996, Galazka 2000a,b).

In Brazil, the National Immunization Program was established in the early 1970s. Although diphtheria control was only achieved in the 1990s, 640 diphtheria cases were notified with an incidence coefficient (IC) of 0.45/100,000

Financial support: Capes, MCT/CNPq, Pronex, Faperj, SR-2/ Uerj

${ }^{+}$Corresponding author: guaraldi@pesquisador.cnpq.br, guaraldi@uerj.br.

Received 16 January 2006

Accepted 5 May 2006 inhabitants at the end of decade. During 2004, 19 cases of diphtheria were reported in the country with an IC of $0.01 /$ 100,000 . Since $1970 \mathrm{~s}$, the vaccine coverage to tetanusdiphtheria toxoid (Td) increased from 66 to $94 \%$. Since 2004, Brazilian immunization policy against diphtheria recommends childhood vaccination at 2,4 , and 6 months of age and booster doses including in adolescents and adults (Brasil 2004). However, there is not much information about regular immunization coverage and immunity of Brazilian adult population (Funasa 2002). In 2002, the Public Health Agency of Rio de Janeiro (SES-RJ 2002) stated a shifting in the age distribution of cases of diphtheria to persons over 15 years of age. A change in epidemiological aspects of diphtheria has been also recently observed in São Paulo (Casagrande et al. 2005). Current information also indicated the circulation of Corynebacterium diphtheriae in our population, including cancer patients (Mattos-Guaraldi et al. 2001a) and healthy vaccinated adults (Mattos-Guaraldi et al. 2001b). Recent investigations on the prevalence of $\mathrm{IgG}$ anti-diphtheria toxin levels in blood donors from Rio de Janeiro showed that only $30 \%$ of adults were fully protected. However, investigation on the circulating neutralizing toxin antibody levels in the vaccinated population remains necessary, especially for individuals with titers $<0.1 \mathrm{IU} / \mathrm{ml}$ of specific $\mathrm{IgG}$ (Damasco et al. 2005). The aim of this study was to assess functional antibody levels against diphtheria toxin among healthy blood donors living in Rio de Janeiro.

The survey analyzed 140 sera from a random sample of 240 blood donors of Hospital Universitário Pedro Ernesto, Universidade do Estado do Rio de Janeiro (Hupe/ Uerj) collected from July to October 2002. The study protocol was approved by The Institutional Review Board of 
the University Hospital, and blood donors were included in the study after signing a written informed consent. Healthy adults included individuals from 18 to 61 years old, stratified by age and sex: median age of 34 years; 53 $(37.8 \%)$ female, and $87(62.2 \%)$ male. A total of $119(85.5 \%)$ subjects reported basic childhood diphtheria immunization. Serum samples were frozen and stored at $-70^{\circ} \mathrm{C}$ until performance of diphtheria toxin antibody test.

Serum samples were tested for specific anti-diphtheria toxin neutralizing antibodies using a microtitre plate as previously described (Mills et al. 2003). Briefly, Vero cells were grown in modified Eagle's medium (MEM) supplemented with $10 \%$ fetal calf serum. A volume of $50 \mu 1$ of serial twofold dilutions of undiluted test sera or standard serum for diphtheria toxin, initially diluted at $1 / 200$ (equine antiserum from Instituto Vital Brazil, RJ, Brazil; $1000 \mathrm{IU} / \mathrm{ml}$ of antibody to diphtheria toxin) were added to the plates. Following incubation of plates with diphtheria toxin $(80$ $\mathrm{pg} / 50 \mu \mathrm{l})$ at $37^{\circ} \mathrm{C}$ for $1 \mathrm{~h}, 100 \mu \mathrm{l}$ of Vero cells $\left(2.5 \times 10^{5}\right.$ cells/ $\mathrm{ml}$ ) were added to each well. The neutralizing effects of antibodies were evaluated by growth of Vero cells after 4 days of incubation at $37^{\circ} \mathrm{C}$. Neutralizing antibody titer was defined as the highest dilution of serum neutralizing toxin killing of $50 \%$ Vero cells $\left(\mathrm{CD}_{50}\right)$. Viability of cells was determined, by the MTT assay (Efstratiou et al. 1998). Neutralizing antibody levels were expressed as IU/ml calculated from the standard serum and were categorized according to internationally accepted ranges: < $0.01 \mathrm{IU} /$ $\mathrm{ml}$ (non-protective), between 0.01 to $0.09 \mathrm{IU} / \mathrm{ml}$ (basic protection), $\geq 0.1 \mathrm{IU} / \mathrm{ml}$ (full protection). The lowest protective level of serum neutralizing antibody to diphtheria is considered as $>0.01 \mathrm{IU} / \mathrm{ml}$ (Galazka 1993).

Data analysis was carried out using the Epi Info ${ }^{\mathrm{TM}}$ software program version 6.03 developed by the Centers for Disease Control and Prevention (CDC, Atlanta, GA, US).

Diphtheria antitoxin production, primarily of IgG type, can be induced by absorption of native toxin during clinical infection or in the carrier state, or by immunization with diphtheria toxoid (Walory et al. 2000). Protection against diphtheria is mainly due to the development of neutralizing toxin antibodies. It is believed that a circulating diphtheria antitoxin level of $0.01 \mathrm{IU} / \mathrm{ml}$, as determined by the neutralization test in animals or in cell culture, provides clinical immunity against disease. The outcome of revaccination of adults depends on several factors, in- cluding the immunization schedule, potency and time since the last dose of toxoid (Galaska 1993).

In developing countries where diphtheria is endemic, the process of maintaining immunity usually operates through natural mechanisms, including frequent skin infections caused by $C$. diphtheriae. Nowadays, adults might become susceptible to diphtheria due to reduced opportunities of sub clinical infections. Since diphtheria infection may also occur among previously vaccinated persons (Mattos-Guaraldi et al. 2001b), the immunity gap observed among adults should be closed by regular diphtheria boosters (Ohuabunwo et al. 2005).

Preliminary studies on IgG diphtheria antitoxin levels determined by means of an ELISA showed basic immunity in 66.7 and $90.9 \%$ of children ( $0-14$ years) and teenagers (15-20 years), respectively (Filardy et al. 2001). The lack of information on the immunity status against diphtheria in Brazilian adults prompted us to analyse $\mathrm{IgG}$ levels anti-diphtheria toxoid in healthy individuals aged 1861 years. The results indicated that only $30.7 \%$ of individuals were fully protected (Damasco et al. 2005). Herein, data presented in the Table illustrated the distribution by age of antitoxin neutralizing antibody levels among Rio de Janeiro citizens blood donors. Of note, only $27.1 \%$ of individuals showed antibody levels $\geq 0.1 \mathrm{IU} / \mathrm{ml}$ considered to be protective against diphtheria. Most individuals $(42.1 \%)$ had antibody levels between 0.01-0.09 IU/ml and are considered partially protected against the disease. However, a great proportion $(30.7 \%)$ of individuals remains vulnerable to disease due to a lack of specific antibody $(<0.01 \mathrm{IU} / \mathrm{ml})$.

Among unprotected individuals, $26.6 \%$ were from the age group of 18-30 years. The high percentage of individuals (72.8\%) presenting diphtheria antitoxin levels < $0.1 \mathrm{IU} / \mathrm{ml}$ suggests a significantly higher risk of diphtheria among adults in our community. Nevertheless, the current strategy of mass immunization during childhood may indeed be sufficient to prevent major outbreaks due to generation of memory cells. Despite this hypothesis, epidemic diphtheria has re-emerged on a massive scale in the Newly Independent States (NIS) of the former Soviet Union, beginning in 1990 and affecting 15 countries by the end of 1994, with more than 175,000 reported cases and 5000 deaths before immunization campaigns controlled the epidemic. Diphtheria epidemics also spreaded to neighbouring countries in Europe, the Middle East and

TABLE

Neutralizing-antibody levels to diphtheria toxin in blood donors stratified by age

\begin{tabular}{|c|c|c|c|c|c|c|c|c|c|}
\hline \multirow[b]{3}{*}{ Age groups (years) } & \multicolumn{9}{|c|}{ Titers (IU/ml) } \\
\hline & \multicolumn{3}{|c|}{$<0.01$} & \multicolumn{3}{|c|}{ 0.01-0.09 } & \multicolumn{3}{|c|}{$>0.1$} \\
\hline & $n$ & $\%$ & CI $95 \%$ & $n$ & $\%$ & CI $95 \%$ & $n$ & $\%$ & CI $95 \%$ \\
\hline $18-30(n=60)$ & 16 & 26.6 & $16.6-38.8$ & 28 & 46.6 & $34.3-59.2$ & 16 & 26.6 & $16.6-38.8$ \\
\hline $31-40(n=45)$ & 13 & 28.8 & $17.2-43.3$ & 20 & 44.4 & $30.4-59.0$ & 12 & 26.6 & $15.3-40.9$ \\
\hline $41-50(n=24)$ & 10 & 41.6 & $23.4-61.7$ & 8 & 33.3 & $16.8-53.6$ & 6 & 25.0 & $10.8-44.9$ \\
\hline $51-61(n=11)$ & 4 & 36.3 & $12.7-66.3$ & 3 & 27.2 & $7.4 .5-57.8$ & 4 & 36.3 & $12.7-66.3$ \\
\hline Total $(n=140)$ & 43 & 30.7 & $23.4-38.7$ & 59 & 42.1 & $34.1-50.4$ & 38 & 27.1 & $20.2-34.9$ \\
\hline
\end{tabular}


Asia. According to literature, control of diphtheria epidemics in vaccine era requires high levels of immunity among all age groups of the population (Galazka 2000a,b, Ohuabunwo et al. 2005).

The heterogeneous selection criteria for the participants and serological methods used for determining immunity to diphtheria make difficult to establish reliable comparisons of data from different epidemiological studies (Corbeira et al. 1999). However, data achieved in other countries in which antitoxin antibody concentrations were measured by neutralization test (Kjedlsen et al. 1988, Rappuoli et al. 1993, Mathei et al. 1997, Edmunds et al. 2000, Marlovits et al. 2000, McQuillan et al. 2002), demonstrated a low percentage of immunity against diphtheria in healthy adults, as observed in this study.

The present evaluation of neutralizing antibodies showed that the highest percentage $(41.6 \%)$ of subjects susceptible to diphtheria was in the age group of 41-50 years old. During epidemic in Eastern Europe the highest mortality rate $(62 \%)$ was also detected in this age group (Rakhmanova et al. 1996, Brennan et al. 2000, Ohuabunwo et al. 2005).

Questionnaires answered by blood donors revealed that $119(85 \%)$ had history of basic diphtheria immunization during childhood. In this group, $28.5 \%$ and $42 \%$ showed diphtheria neutralizing antibody titers $<0.01 \mathrm{IU} /$ $\mathrm{ml}$ and between $0.01-0.09 \mathrm{IU} / \mathrm{ml}$, respectively. Only $29.4 \%$ of subjects showed protective levels of neutralizing antibodies to diphtheria $(\geq 0.1 \mathrm{IU} / \mathrm{ml})$.

We believe that the vast territory and unfavorable economic conditions presented by most regions of our country turn difficult the notification of cases to Public Health authorities and remittance of suspect isolates for bacteriological confirmation and toxigenicity tests to reference laboratories. Local outbreaks have been reported indicating gaps or failure in vaccine coverage (Mattos-Guaraldi et al. 2001b).

In general, diphtheria has become rare in immunized populations despite the lack of protective antibody titers in large proportion of the adult population. Some authors questioned the validity of accepted cut-off values for diphtheria protective titers. They believe antibodies wane with time after complete basic immunization while immunological memory persists, discarding the need for adult boostering (Mathias 1985). Nevertheless, during the diphtheria resurgence in parts of Eastern Europe, 60-70\% of reported cases were among persons aged 15 years and older (Galazka \& Robertson 1996). Therefore, if immunological memory generated by vaccination in childhood is enough to protect adult individuals, without additional booster doses, needs further investigations.

This seroepidemiologic survey indicates a low prevalence of diphtheria neutralizing antibody levels in healthy adults from Rio de Janeiro, Brazil, with 30.7\% (95\%, CI: 23.4-38.7) of individuals presenting titers $<0.01 \mathrm{IU} / \mathrm{ml}$. The existence of susceptible adults creates an epidemic potential in our community and reinforces the need of introduction and surveillance of $\mathrm{Td}$ vaccination for adults in order to ensure adequate diphtheria neutralizing antibody levels.

\section{ACKNOWLEDGEMENTS}

To Dr Selma M Brito and José Henrique da Silva, Hupe/ Uerj, for assistance in blood samples collection.

\section{REFERENCES}

Brasil 2004. Ministério da Saúde, Portaria nº 597/GM, Brasilia.

Brennan M, Vitek C, Strebel P, Wattigney W, Bisgard K, Brisgalov S, Bragina V, Pyanikh V, Wharton M 2000. How many doses of diphtheria toxoid are required for protection in adults? Results of a case-control study among 40 to 49 years-old adults in the Russian Federation. J Infect Dis 181: S193-196.

Casagrande ST, Garbelloti M, Kobata AM, Mello MLR, Hidalgo NT 2005. Diagnóstico laboratorial da difteria e a prática da coleta de material de comunicantes como estratégia da vigilância epidemiológica - Grande São Paulo, 1987 a 1996. Epidemiol e Serv Saúde 14: 181-190.

Corbeira PG, Dal-Ré R, De Lomas JG, Aguilar L 1999. Low prevalence of diphtheria immunity in the Spanish population: results of a cross-sectional study. Vaccine 17: 19781982.

Damasco PV, Pimenta, FP, Filardy AA, Brito SM, Andrade AFB, Lopes GS, Hirata Jr R, Mattos-Guaraldi, AL 2005. Prevalence of $\mathrm{IgG}$ diphtheria antitoxin in blood donors in Rio de Janeiro. Epidemiol Infect 133: 911-914.

Edmunds WJ, Pebody, RG, Aggerback H, Baron S, Berbers G, Conyn-Van Spaendonck MAE, Hallander HO, Orlander R, Maple PAC, De Melker HE, Olin P, Fievret-Groyne F, Rota C, Salmaso S, Tischer A, Von-Hunolstein C, Miller E 2000. The sero-epidemiology of diphtheria in Western Europe. Epidemiol Infect 125: 113-125.

Efstratiou A, Engler KH, Dawes CS, Sadic D 1998. Comparison of phenotypic and genotypic methods for detection of diphtheria toxin among isolates of pathogenic corynebacteria. J Clin Microbiol 36: 3173-3177.

Filardy AA, Hirata Jr R, Villela LHC, Napoleão F, Formiga LCD, Andrade AF, Mattos-Guaraldi AL 2001. Potential susceptibility to diphtheria among adolescents and adults in Rio de Janeiro. In XXI Congresso Brasileiro de Microbiologia, Anais, p. 59.

Funasa - Fundação Nacional de Saúde 2002. Difteria: situação atual da doença. Available from URL: http://www. funasa.gov.br/guia_epi/htm/doenças/difteria/index. htm.Mar23

Galazka AM 1993. The immunological basis for immunization series. Module 2: Diphtheria. World Health Organization, WHO/EPI/GEN/93.12.

Galazka AM 2000a. The changing epidemiology of diphtheria in the vaccine era. J Infect Dis 181: S2-9.

Galazka AM 2000b. Implications of the diphtheria epidemic in the former Soviet Union for immunization programs. J Infect Dis 181: S244-248.

Galazka AM, Robertson SE 1996. Immunization against diphtheria with special emphasis on immunization of adults. Vaccine 14: 845-857.

Kjeldsen K, Simonsen O, Heron I 1988. Immunity against diphtheria and tetanus in age group 30-70 years. Scand Infect Dis 20: 177-185. 
MacQuillan GM, Kruszon-Moran D, Deforest A, Chu S, Wharton M 2002. Serologic immunity to diphtheria and tetanus in the United States. Ann Intern Med 136: 660-666.

Marlovits S, Stocker R, Efstratiou A, Brougton K, Kaider A, Vecsei V, Wiedermann G, Kollristsch H 2000. Seroprovalence of diphtheria immunity among injured adults in Austria. Vaccine 19: 1061-1067.

Mathei C, Van Damme P, Bruyneseels P, Goossens H, Vranckx R, Meheus A 1997. Diphtheria immunity in Flanders. Eur J Clin Microbiol Infect Dis 16: 631-636.

Mathias RG, Schechter MT 1985. Booster immunization for diphtheria and tetanus: no evidence of need in adults. Lancet $i$ : 1089-1901.

Mattos-Guaraldi AL, Formiga LCD, Camello TCF, Pereira GA, Hirata Jr R, Faria LMD, Halpern M 2001a. Corynebacterium diphtheriae threats in cancer patients. Rev Argentina Microbiol 33: 96-100.

Mattos-Guaraldi AL, Formiga LCD, Marques EA, Pereira GA, Moreira LO, Pimenta FP, Camello TCF, Oliveira EF 2001b. Diphtheria in vaccinated adult in Rio de Janeiro. Braz, J Microbiol 32: 236-239.

Mattos-Guaraldi AL, Moreira LO, Damasco PV, Hirata Jr R 2003. Diphtheria remains a threat to health in developing world - An overview. Mem Inst Oswaldo Cruz 98: 987993.

Mills KHG, Cosgrove C, McNeela EA, Sexton A, Giemza R,
Jabbal-Gill I, Church A, Lin W, Illum L, Podda A, Rappuoli R, Pizza M, Griffin GE, Lewis DJM 2003. Protective levels of diphtheria - neutralizing antibody induced in healthy volunteers by unilateral priming-boosting intranasal immunization associated with restricted ipsilateral mucosal secretory immunoglubulin A. Infect Immun 71: 726-732.

Ohuabunwo C, Perevoscikovs J, Griskevica A, Gargiullo P, Brilla A, Viksna L, Glismann S, Wharton M, Vitek C 2005. Respiratory diphtheria among highly vaccinated military trainees in Latvia: improved protection from DT compared with Td booster vaccination. Scand J Infect Dis 37: 813820.

Rakhmanova AG, Lumio J, Groundstroem KAJ, Valova E, Nosikova E, Tanasijchuk T, Saikku J 1996. Diphtheria outbreak in Saint Petersburg: clinical characteristics of 1,860 adult patients. Scand J Infect Dis 28: 37-40.

Rappuoli R, Podda A, Giovannoni F, Nencioni L, Peragallo M, Francolini P 1993. Absence of protective immunity against diphtheria in a large proportion of young adults. Vaccine 11: 576-577.

SES-RJ - Secretaria de Saúde do Estado do Rio de Janeiro 2002. Proporção de casos e óbitos por difteria segundo faixa etária, 1978-2002. SES-RJ/SUSC/CE/Assessoria de Doenças Imunopreviníveis.

Walory J, Grzesiowski P, Hryniewicz W 2000. Comparison of four serological methods for the detection of diphtheria antitoxin antibody. J Immunol Methods 245: 55-65. 